\title{
2
}

\section{Advancing Transnational Approaches to Social Protection in the Global South}

\author{
Amanda Shriwise
}

\section{Introduction}

The suggestion that social protection arrangements have transnational underpinnings is not new (e.g. Yeates 2001). An increasing number of social scientists have recognized the extent to which transnational dynamics, including those surrounding colonialism and conflicts (Obinger et al. 2018; Schmitt 2015; Obinger and Schmitt 2011), have affected the emergence of social protection systems and welfare regimes (Wood and Gough 2006). Transnational actors, such as international nongovernmental organizations, multi- and transnational corporations, trade unions and Churches, continue to impact social protection arrangements in the Global South as they have since colonial times, and indeed much of the literature on social protection has focused on the role of these actors (Deacon 2007, 2013a, b). Furthermore, both national (Slaughter

\section{A. Shriwise $(\bowtie)$}

SOCIUM Research Center on Inequality and Social Policy,

University of Bremen, Bremen, Germany

e-mail:shriwise@uni-bremen.de 
2004) and intergovernmental (Cronin 2002) actors have been recognized as having the ability to act transnationally, despite their respective national and international governance arrangements.

Transnational perspectives are not meant to replace a focus on national actors and domestic conditions but rather to complement them and to promote a more comprehensive understanding of social policymaking, particularly in cases where external actors may be pivotal. While recognizing the transnational nature of a number of social problems, intergovernmental efforts to address them rightly acknowledge the continued salience of the nation state and national actors. Both the International Labour Organization's emphasis on establishing social protection floors and the World Health Organization's push to achieve universal health coverage focus on working with countries to achieve these goals in the context of the United Nations (UN) 2030 Agenda for Sustainable Development. Equally, the 2030 Agenda stresses the need to build strong partnerships and institutions to support implementation efforts in countries by working transnationally, including through the promotion of effective public-private partnerships as well as through partnerships with international non-governmental and civil society organizations (United Nations General Assembly 2017).

This chapter examines how transnational approaches to social protection can advance our understanding of welfare arrangements in the Global South in a way that maximizes contributions to theory-building. Using a transnational lens to examine the key actors and institutions affecting social protection arrangements can help to illuminate the origins, asymmetries and ideas that have impacted these arrangements in the Global South. The chapter argues that transnational approaches must move beyond a recognition that context matters in policymaking to identifying causal patterns that can inform social policymaking on a global scale. While transnational perspectives are not a panacea for problems within the social policy literature, they are a necessary first step toward advancing theoretical development in ways that are empirically grounded and relevant for policymaking in the present.

The chapter proceeds as follows. First, it reviews understandings of the transnational across relevant disciplines to find common ground. Then, in the third section, the chapter defines transnational actors and their 
relationship to global institutions with respect to social protection. The fourth section examines how analyzing the dynamics of transnational actor constellations might contribute to theory-building by identifying causal patterns across country cases in relation to recent advances in social protection in the Global South. The final section concludes by summarizing these interdisciplinary insights and reflecting on how they can best support theory and practice in the area of social protection.

\section{Understandings of the Transnational: Finding Common Ground}

Transnational approaches to social policy have been described as a "means of revealing the constructed parameters of the "national'" (Yeates and Irving 2005, 403). As argued by Clarke (2005, 414), "The idea of the transnational draws our attention to processes that work in and across nations". As an inherently interdisciplinary area of study, viewing social policy through a transnational lens can mean different things to scholars from different disciplines. This section explores the range of definitions of the transnational employed by sociologists, political scientists and international relations (IR) as well as legal scholars that are relevant for understanding the emergence of social protection in the Global South.

Sociologists take a broad approach to the transnational, understanding it as the study of social structures and processes that transcend or go beyond the national, often with a focus on the way in which the global and the national are constituent parts of each other. For example, as described by Sassen $(2006,2010,1-2)$, "the global-whether an institution, a process, a discursive practice, an imaginary-both transcends the elusive framing of national states and also partly emerges and operates within that framing. ... Further, if the global gets partly structured inside the national, then the methodological and theoretical challenges to statecentric social sciences will be different from those posed by the common binary of global vs. national."

Sociologists also make strong distinctions between state and society, which opens up space for considering: (1) societal relationships beyond 
national borders, (2) how national actors impact social protection beyond their geo-political boundaries and (3) how transnational actors and transnational social movements affect policymaking. The need to view social protection through a transnational lens has been emphasized by migration scholars in particular, whose work stems largely from a recognition that a growing number of individuals and families are socially embedded in multiple societies across national boundaries (Levitt and Jaworsky 2007; Levitt and Nyberg-Sørensen 2004; Levitt 2001). This research illuminates how the production and acquisition of social protection is distinct for individuals and families living transnational lives in ways that concepts such as social citizenship and the study of national welfare regimes does not fully capture and may even occlude (Faist et al. 2015; Levitt et al. 2017).

When examining transnational dynamics, political scientists and IR scholars focus on governance and have increasingly taken an actor-centric approach. Global social governance has been defined as "a multi-actored process of shaping global and national social policies" (Kaasch and Martens $2015,7)$. Here, the global and national are distinguished by both the level at which such policymaking processes take place and the scale on which they seek to make an impact. In a global governance context, policymaking occurs within "political arrangements which rely primarily on nonhierarchical forms of steering. ... In other words, governance beyond the nation-state means creating political order in the absence of a state with a legitimate monopoly over the use of force and the capacity to enforce the law and other rules authoritatively" (Risse 2006, 180).

The IR literature distinguishes between two types of global governance arrangements affecting global and national policymaking, depending on the actors involved: intergovernmental and transnational. Intergovernmental governance refers to processes in which states seek to move behavior toward a shared public goal; transnational governance refers to the same process but for non-state actors (Roger and Dauvergne 2016). Similar to the way in which the welfare mix recognizes both the public and private dimensions of national social policies, the umbrella of global social governance includes both intergovernmental and transnational governance arrangements with respect to social policy. The strong affinity between what is considered to be private and transnational within the 
IR literature has three key effects. First, it narrows understandings of the transnational compared to sociological understandings. Second, the notion of transnational as private can imply that what is transnational is not public and is therefore separate, beyond and/or exempt from governmental intervention. Third, it siloes discussions of intergovernmental and transnational governance mechanisms and obscures links between them. This makes it more difficult to discern the transnational dynamics underpinning social protection arrangements, particularly in developing country contexts.

Like social policy, legal scholarship is inherently interdisciplinary, and broad and narrow understandings of the transnational exist within this literature as well. Similar to the way in which migration scholars shed light on the unique nature of social protection arrangements for individuals and families living transnational lives, a recognition of transnational law has arisen in part because of the emergence of legal problems that are not solely national, international, public or private. Some legal scholars treat transnational law as pertaining predominantly to private actors, but in ways that transcend national understandings of both the "state" and "market" (Calliess 2007; Calliess and Zumbansen 2010; Zumbansen 2011). Alternatively, Jessup (2006, 45) defines transnational law broadly as "all law which regulates actions or events that transcend national frontiers" (Cotterrell 2012, 501). Under this definition, transnational law can address a range of public and private actors, including states, intergovernmental organizations, international and national nongovernmental organizations, civil society organizations and families.

In a fashion somewhat akin to distinctions between social policies and social policymaking, transnational legal scholars recognize transnational law as substantive, part of an ongoing process and inherently normative. Substantive understandings of transnational law "emphasize the way regulatory regimes seek uniformity across limited (usually functionally defined) transnational operational spheres" (Cotterrell 2012, 501). This can be achieved either by harmonizing unique sets of national, international, public and private laws that pertain to transnational activities in a way that promotes legal pluralism (Zumbansen 2011) or in a way that promotes convergence and universal approaches toward transactions that "move[s] toward a "world law"” (Cotterrell 2012, 501). Process-based 
understandings of transnational law tend to be broader and have been defined as "the theory and practice of how public and private actorsnation-states, international organizations, multinational enterprises, non-governmental organizations, and private individuals - interact in a variety of public and private, domestic and international fora to make, interpret, enforce, and ultimately, internalize rules of transnational law" (Koh 1996, 183). Finally, both substantive and process-based understandings of transnational law stress the importance of norms for bringing actors into compliance. While an actor may choose not to comply with transnational rules and standards at a given point in time, norms may affect the degree to which an actor will deviate from established norms, and most actors will align with dominant norms over time-a testament both to the durability of the substance of the law and to the legitimacy of the process through which laws have been created. In the case of social protection, this perspective suggests that just because every country does not yet have a social protection floor does not mean that they will never have one, nor does it mean that the Social Protection Floors Recommendation, 2012 (No. 202) is without teeth.

Understanding social policy from a transnational perspective can mean many different things to different scholars, depending largely on one's disciplinary vantage point. Sociologists are likely to focus on the ways in which the social transcends the national, as in the case of transnational migration, and also on the ways in which global social policies, such as social protection floors, are both constitutive of, and constituted by, national actors and interests. For political scientists and IR scholars, there is a close affinity between the private and the transnational, which makes it difficult to discern how transnational governance arrangements impact social protection. While some legal scholars also view transnational law as pertaining predominantly to private actors, there is broad agreement that transnational law pertains to cross-border activities for which there is no singular approach by the state. From a process view, transnational law recognizes that national, international, public and private actors all play a role in its emergence and realization. Building on Koh (1996, 184), understanding social policy from a transnational perspective suggests that social protection arrangements in the Global South may be: (1) pluralistic; (2) non-statist, but may include state actors; (3) dynamic and mutually constitutive; and (4) normative. 


\section{Transnational Actors and Social Protection}

It is important to distinguish between viewing social protection through a transnational lens and understanding the role of transnational actors in social protection arrangements throughout the Global South. As discussed later in this volume by Barrientos (Chap. 13), transnational actors have received a great deal, arguably a disproportionate amount, of attention within the literature on social protection. Here, the focus on transnational actors is not meant to suggest that both domestic and indigenous actors and domestically driven, state-oriented processes have not played a critical or even determining role in social protection in the Global South, because indeed they have. Furthermore, while there are many transnational underpinnings of social protection in the Global South, it is important to acknowledge that social protection continues to be framed predominantly as a national policy issue, not least because the nation state remains the political unit of the international system. These trends are stated explicitly in the 2030 Agenda, which encourages the implementation of "nationally appropriate social protection systems and measures for all, including floors" (United Nations General Assembly 2017, 1).

The application of a transnational lens to policymaking processes and more detailed understandings of the inner workings of intergovernmental organizations have challenged traditional definitions of transnational actors as private, non-state actors affecting global politics. Under traditional definitions, key transnational actors in relation to social protection in the Global South include firms, Churches and missionaries, trade unions and other non-governmental organizations. However, scholars such as Cronin (2002) illustrate how attention to the way in which UN agencies approach policy implementation across countries swiftly blurs the boundaries IR scholars have established between intergovernmentalism and transnationalism. Whether through contracting nongovernmental organizations or consultants, creating expert advisory groups, facilitating trainings and capacity building or accepting funding from large philanthropic foundations, these activities regularly involve parties beyond governments alone. The need to work with and through 
non-governmental agencies is even emphasized in the current 2030 Agenda which aims to "encourage and promote effective public, publicprivate and civil society partnerships" arrangements (United Nations General Assembly 2017, 21), including in the implementation of social protection arrangements. In sum, while the governance mechanisms underpinning intergovernmental and private transnational actors may differ, the way in which these entities act and approach social policy implementation across borders may be much more similar than different. For this reason, it is important to recognize transnational actors as a group that is broader than and distinct from the governance arrangements that underpin them.

Second, the behavior of transnational actors is often difficult to characterize and predict. As illustrated above, transnational actors are autonomous entities capable of exercising agency and taking purposive action (Barnett and Finnemore 2004). This enables transnational actors to act not only in the interest of their members states as recognized by political scientists but also according to their own interests. It also enables them to play a particularly influential role in establishing global norms and fixing meanings (Barnett and Finnemore 2004). As a result of their dual political character, transnational actors may begin to decouple what they say and do about a given policy problem, resulting in incoherence (Bromley and Powell 2012; Meyer and Rowan 1977). Decoupling may happen unintentionally, particularly in situations where there is a lack of clarity or internal disagreement on the interests of a given transnational actor. Alternatively, transnational actors, such as the World Bank (Weaver 2008), may engage in organized hypocrisy (Brunsson 2002, 2007), or the utilization of decoupling as part of a strategy for managing a diverse range of interests. This can make it difficult to discern whether changes in the discourse on social protection among transnational actors bear a relation to substantive policy changes (Shriwise et al. forthcoming).

The dualistic nature of transnational actors, which are mutually constituted on the one hand and yet able to act autonomously on the other, is explained differently by sociologists, political scientists and IR scholars. Sociologists tend to view transnational actors as embedded within systems of global cultural production (Meyer et al. 1997; Boli and Thomas 1997), or a mutually constitutive process where "actors are treated not as 
unanalyzed 'givens' but as entities constructed and motivated by enveloping frames (Jepperson 1992)" (Boli and Thomas 1997, 172). From this view, transnational actors are defined by their unique blend of constituent frames; by extension, this literature places "the institutional character of transnational development front and center" (Boli and Thomas 1997, 172). The institutions at the heart of global cultural production are presumed to be universally valid and applicable across nation states, and the transnational actors embedded within this mutually constitutive system are considered impervious to vested interests, or more simply put, as "objective disinterested others" (Meyer et al. 1997, 160).

Systems of global cultural production also result in the emergence and institutionalization of global norms through an iterative process of interorganizational exchange predominantly between states, intergovernmental organizations and international non-governmental organizations (Kentikelenis and Seabrooke 2017; Babb 2013; Babb and Chorev 2016; Chorev 2012; Halliday and Carruthers 2007). Global social policy scholars have long recognized the politics inherent in these exchanges (e.g. Deacon et al. 1997 and more recently Kaasch 2013), with a recent focus on how international organizations construct social policy proposals (Berten and Leisering 2016). In the case of social protection, the exchange of policy ideas between international organizations has resulted in the emergence of models, or micro-paradigms, of social cash transfers, representing what von Gliszczynski and Leisering $(2016,325)$ refer to as a "fragmented and incomplete universalism". In other cases, transnational actors produce policy scripts for countries to follow in order to achieve nationally and internationally agreed aims, goals and targets; in the case of the International Monetary Fund, evidence suggests that the implementation of scripts focused on various aspects of economic policy have had substantial and long-lasting effects on social protection systems in the Global South (Kentikelenis and Seabrooke 2017; Kentikelenis et al. 2014, 2016; Kentikelenis 2017; Kentikelenis and Papanicolas 2011). The global diffusion of these policies is thought to take place through a number of mechanisms (Dobbin et al. 2007), and in the case of social protection in the Global South, to be driven by a unique set of factors, including jobless agrarianization, heterogeneous political paths 
amid a range of democratic and autocratic regimes, and shifts in the global ideational context (Böger and Leisering 2018).

While sociologists examining systems of global cultural production view nation states as simply another actor defined by its unique set of constituent frames, political scientists and IR scholars recognize that national and transnational actors have different resource bases, interests, capabilities, histories and governance structures that result in power asymmetries. The key insight here is that some actors have played a more influential role than others in shaping the institutional context in which strategic interactions take place. For instance, many national actors in the Global North played an active role in shaping the UN system after World War II, while formerly dependent territories throughout the Global South were instead strongly shaped by notions of sovereignty practiced and perpetuated by this system. Further still, the asymmetries that persist within the international system enable some actors to influence the shape of global institutions themselves — or to change the rules of the game-more than others, resulting in distinct advantages in situations where cooperation is desired (Axelrod and Keohane 1985).

For political scientists and IR scholars, transnational actors are constituent parts of global institutions, defined as "persistent and connected sets of rules that prescribe behavioral roles, constrain activity, and shape expectations" (Keohane 1988, 386). They can be understood in multiple ways. Realist view transnational actors as epiphenomena or as representations of the current balance of power (Strange 1982). This view suggests that powerful, self-interested, rational actors dictate the structure of global institutions and the transnational actors within them, not the other way round. Simply put, many realists see transnational actors as "merely instruments of governments, and therefore unimportant in their own right" (Keohane and Nye 1974). A slightly modified realist perspective is that transnational actors may matter in their own right and prove to be more robust over time when they facilitate and support coordination of an issue area in a way that aligns with the interests of powerful states (Krasner 1982). Finally, transnational actors may be viewed as embedded within a socio-political environment where repeated patterns of behavior result in the emergence of norms that shape and constrain the behavior of actors (Ruggie 1982). While much more aligned with 
sociological understandings of global institutions, these scholars recognize the extent to which global norms both constitute and are constituted by powerful actors, but with a greater stress on the influence of national actors. In other words, the international order itself is an institutional formation in which transnational actors serve as key pillars that uphold asymmetries and guarantee key functions in line with the interests of powerful nation states over time (Ikenberry 2018; Huntington 1973).

Within this context, the set of global institutions in a particular issue area have been referred to across disciplines as regimes, or "sets of implicit or explicit principles, norms, rules, and decision-making procedures around which actors' expectations converge in a given area of international relations" (Krasner 1982, 186). This approach has been applied to welfare as an issue area, both by Esping-Andersen (1990) in his seminal classification of welfare state regimes in the Global North and by Wood and Gough (2006) who extended this work on a global scale. Wood and Gough $(2006,1708)$ argue that countries can be classified as belonging predominantly to one of three types of welfare regimes: welfare state regimes, informal security regimes or insecurity regimes depending on their degree of de-clientelization, or "the process of de-linking client dependents from their personalized, arbitrary and discretionary entrapment to persons with intimate power over them". While this work recognizes that welfare regimes may "spill over national boundaries" (Wood and Gough 2006, 1707) and that multiple welfare regimes may be layered within one country, it falls short of applying a transnational lens to the historical emergence of welfare institutions from the perspective of countries in the Global South, giving this typology more descriptive than explanatory power. Furthermore, the way in which this work extends an institutional approach to welfare devised for rich countries on a global scale divorces an understanding of welfare regimes in the Global South from their micro-foundations. This runs the risk of obscuring rather than clarifying the nature of social policy dynamics in these countries, particularly from the perspective of the domestic and indigenous actors within them.

Finally, political scientists recognize the role of ideas in relation to global institutions and policymaking beyond the establishment of norms 
alone (Béland 2005). As illustrated by Lavers and Hickey (2016, 391), "comparative analysis of social protection interventions in developing countries suggests that ideology has played a significant role, including popular attitudes on who deserves assistance (Graham 2002) and ideas around the responsibility of the state towards its citizens (Hickey 2012)". Furthermore, ideas are inextricably linked to policy implementation preferences and approaches (Devereux and Sabates-Wheeler 2007), with implications for the kinds of policy change the introduction of social protection arrangements represents (Hall 1993). Within the realm of social protection, these debates have centered largely on whether conditional or unconditional cash transfers are most appropriate, which member of the household should receive such transfers and whether health, education and broader forces such as climate change should be considered as integral to social protection arrangements.

In sum, transnational actors appear to be chameleons. Their behavior may be neither coherent nor unitary. They may act independently in line with their own interests or as instruments of powerful nation states, and they may also act in line with broader institutional norms and practices over time. While being influential and present across countries, their presence is not enough to assume that they cause or determine social policy or welfare outcomes in any one country case. Furthermore, the dynamic relationship between transnational actors and global institutions has led both to an interdisciplinary consensus that institutions and norms matter (e.g. Hall and Taylor 1996) and also to varying interpretations of the relationship between transnational actors and global institutions among sociologists on the one hand and political scientists and IR scholars on the other.

However, the consensus that global institutions and norms matter has obscured two key issues: (1) the way in which transnational actors, including intergovernmental organizations, are embedded in national and sub-national structures in ways that can affect social protection (Tarrow 2001); and (2) the impact of domestic actors and conditions on the emergence of social protection arrangements. These problems are representative of the way in which methodological nationalism has affected the examination of social protection across disciplines, where nation states were reified as equal containers and reduced to unitary actors in the 
international order. This is particularly problematic when it comes to understanding policymaking in the Global South, where asymmetries between external and domestic as well as indigenous actors have had criti$\mathrm{cal}$, at times detrimental, and potentially long-lasting effects on the state of social protection dating back to colonialism. There are exceptions to the rule, such as research examining the domestic politics of social protection arrangements in emerging economies in Latin American (Huber and Stephens 2012). However, substantial gaps remain in properly joining up the micro-foundations of policymaking at the level of actors within countries in the Global South with what is known about transnational actors and global institutions across disciplines. The question then remains: How can transnational approaches help scholarship move beyond methodological nationalism and strengthen its micro-foundations so as not to perpetuate global institutional and ideational determinism when seeking to explain social protection arrangements in the Global South?

\section{From Context to Causation: Analyzing Transnational Actor Constellations}

To better understand the transnational policymaking dynamics underpinning social protection arrangements, one useful tactic is to move one level below institutions, both global and national, and to focus instead on the transnational actor constellations affecting social protection from the perspective of countries in the Global South. A transnational actor constellation can be defined as a group or network of actors involved in policy interactions that either includes transnational actors or is impacted substantially by transnational relationships, with the assumption that "a thorough understanding of the underlying constellation is an essential precondition for the explanation and prediction of interaction outcomes" (Scharpf 1997, 16). While every actor or relational element that constitutes an actor constellation need not be transnational, the presence of transnational actors and relations that affect the dynamic of these constellations is what identifies them as transnational. Equally, it should be 
noted that a transnational approach is defined by consideration of the possibility of transnational actors and relationships being substantial elements of a policy process; if neither of these criteria proves to be true empirically, the relevant actor constellation might best be described as national or global or urban, depending on definitions and empirics. In these cases, the consideration that actor constellations may be transnational amounts to necessary due diligence in line with what is expected from working hypotheses and the possibilities suggested by existing literature.

At least two analytical challenges appear when using transnational actor constellations as a unit of analysis: identifying the actors and determining causation. Developing strong criteria for actor identification is critical, not least because it shapes the data and information considered when describing transnational actor constellations from the outset and subsequently the findings and conclusions that can be drawn concerning their dynamics. Current literature on global social policy provides actor matrices that can be used as deductive frames for identifying key actors involved in social policymaking to avoid biasing analyses based on data availability and available literature. Building on the work of EspingAndersen (1990), both Wood and Gough (2006, 1701) as well as Yeates (2001) recognize the importance of considering both domestic and transnational actors and institutions central to the operation of states, markets, communities and families in order to understand the social policy dynamics within countries across the Global South. For the purpose of identifying actors relevant for social protection, these deductive frames should be as inclusive as possible, and when key actors and institutions not previously considered are found to have causal effects on social protection arrangements, these new elements should be incorporated into future deductive frames.

Determining how to understand causation within these constellations is a much more difficult matter. While the study of transnational phenomena has been largely interdisciplinary, it has also been described as "'undisciplined' in its use of diverse concepts, theories and literature. ... Besides a few exceptions ... shared theoretical frameworks or concepts on transnational processes across the subfields are comparably lacking" (Go and Krause 2016, 6). Indeed, understandings of the dynamics of these 
constellations are likely to differ according to disciplinary understandings of the relationship between transnational actors and global institutions as discussed above. Furthermore, as highlighted by Obinger et al. (2013, 121), "comparative welfare state research has only recently begun to systematically study relational policy processes". In this area, transnational legal scholarship has parallels with social policy in the way it is conceptualizing transnational processes. Koh $(2006,745-746)$ suggests that law is either downloaded from international to domestic law, uploaded from domestic law to international law or horizontally transferred from one national system to another. This aligns closely with the concluding observation from Obinger et al. $(2013,124)$ that "the systematic combination of processes of horizontal spatial interdependencies with vertical relationships between international and supranational institutions and their member states ... is perhaps the biggest challenge for future research”. As a unit of analysis, transnational actor constellations bring these processes and their component parts into focus in order to better understand their dynamics.

There is a plethora of information on country experiences in relation to social protection in the Global South from intergovernmental organizations, international non-governmental organizations, think tanks, consultancies, country reports and academic literature. However, all too frequently, case studies attribute their unique or distinguishing features to differences in country context, without a serious and detailed exploration of what this means and what, if any, theoretical implications these claims have. To break through this impasse, it will be necessary for global social policy scholarship: (1) to continue to develop a coherent and pluralistic discourse on the theoretical and conceptual frameworks being used to support the analysis of transnational actor constellations with respect to social policy in the Global South; and (2) for case studies to be both better harnessed and more specifically designed to contribute to theoretical and conceptual development.

Process tracing supports the discovery and re-construction of how policy dynamics play out in practice. Within the context of transnational actor constellations, tracing the development and implementation of social protection arrangements can contribute both to theory-building and, in carefully selected cases, to theory testing (Beach 2016). Ulriksen 
and Dadalauri $(2016,223)$ illustrate how well-designed single case studies can "contribute to the testing and modification of solid theoretical frameworks undertaken through a rigorous research design that ensures substantial empirical leverage and constructive conclusions". The use of case studies in this way is both possible and important for at least two related reasons. First, using process tracing in a single, most crucial case (Gerring 2007) provides a means of evaluating "theoretically specified causal mechanisms that link variables in a comprehensive and temporal explanation of interesting societal phenomena" (Ulriksen and Dadalauri 2016, 225). While this use of case studies should complement and cannot replace testing focused on explaining variance between an independent and dependent variable, confirming and specifying the causal mechanisms at play has implications for policy practice. Uncovering causal mechanisms within a transnational actor constellation with regard to social protection provides policymakers with critical information and perspective about the context in which they are operating and can, at best, enable them to respond with agility and ingenuity to challenges and barriers. Moreover, if policymakers are better informed and able to act on the best available knowledge, their experiences are also better able to inform theoretical development, creating a much more productive and mutually beneficial relationship between academic research and policy practice with respect to social protection.

\section{Conclusion}

Across disciplines, scholars have focused increasingly on the ways in which transnational dynamics have affected social protection in the Global South. Together, research across disciplines suggests that social protection arrangements in the Global South will be: pluralistic; nonstatist, but may include state actors; dynamic and mutually constitutive; and normative. While a transnational approach is not a substitute or replacement for a focus on national actors and domestic conditions, it draws attention to the role of transnational actors in social policymaking, encouraging critical engagement and examination of their behavior and activities. Literature from across disciplines reveals that these actors 
appear to be chameleons. Their behavior may not be coherent or unitary, and they may behave in line with their own interests or as instruments of powerful nation states that govern them. Examination of these actors and the ways in which they impact and are impacted by global institutions has resulted in an interdisciplinary consensus that global institutions and norms matter. However, the methodological nationalism inherent in much of this work has masked the relationship between global institutions and norms and national and sub-national environments and structures as well as the impact of domestic actors and conditions on the emergence of social protection arrangements.

Identifying and analyzing transnational actor constellations is one way of encouraging the development of stronger micro-foundations in global social policy research in order to gain a much more specific understanding of the interplay between external actors and domestic conditions when it comes to social protection. As policies have proven to 'work' in some country contexts and not in others, policymakers and academics alike continue to espouse the need to tailor and adapt policies to their particular political and institutional contexts, and this rightly remains a hallmark of global policymaking to date. However, this leaves a critical theoretical and practical gap, as attention to context does not help to determine causality. Given the inherently interdisciplinary nature of global social policy research, it is critical that scholars continue to develop a coherent and pluralistic discourse on the theoretical and conceptual frameworks being used to analyze transnational actor constellations and social protection arrangements in the Global South. Within this frame, the plethora of information on country cases and social protection can be better harnessed, and carefully designed case studies and process tracing can be conducted in ways that can help to build, revise and test theories. This is a necessary complement to cross-country quantitative research, as thorough and more specific understandings of the dynamics of transnational actor constellations are critical to informing policy practice, and ideally by extension, to enhancing social protection. From a theoretical standpoint, the study of transnational actor constellations in relation to social protection can promote a better understanding of the relational 
elements underpinning social protection arrangements in the Global South, which has been identified as "perhaps the biggest challenge for future research" (Obinger et al. 2013, 124).

Understanding social policy from a transnational perspective is becoming increasingly important in the context of the 2030 Agenda. The ways in which social protection is affected by cross-border social problems, ranging from disease to migration to environmental degradation, is demonstrated on an almost daily basis. Broader understandings of the transnational could advance global social governance and policymaking by illuminating the relationships and divisions between intergovernmental and transnational governance mechanisms. Looking at how both of these sets of governance mechanisms impact each other with regard to social rights, redistribution and regulation may lead to particularly insightful findings related to social protection. Also, the chameleon-like behavior of transnational actors makes them an intriguing focal point for interdisciplinary researchers, as they present conceptual and analytical challenges that appear to defy explanation from the dispositions of sociologists as well as political scientists and IR scholars alone. Such work is of critical and timely importance. Theory-driven research, in addition to being important in its own right, has the potential to better inform policy practice and to support efforts to ensure that no one is left behind when it comes to social protection.

\section{References}

Axelrod, Robert, and Robert O. Keohane. 1985. Achieving Cooperation under Anarchy: Strategies and Institutions. World Politics 38 (1): 226-254.

Babb, Sarah. 2013. The Washington Consensus as Transnational Policy

Paradigm: Its Origins, Trajectory and Likely Successor. Review of International Political Economy 20 (2): 268-297.

Babb, Sarah, and Nitsan Chorev. 2016. International Organizations: Loose and Tight Coupling in the Development Regime. Studies in Comparative International Development 51 (1): 81-102.

Barnett, Michael, and Martha Finnemore. 2004. Rules for the World: International Organizations in Global Politics. Ithaca: Cornell University Press. 
Beach, Derek. 2016. It's All About Mechanisms-What Process-Tracing Case Studies Should Be Tracing. New Political Economy 21 (5): 463-472.

Béland, Daniel. 2005. Ideas and Social Policy: An Institutionalist Perspective. Social Policy and Administration 39 (1): 1-18.

Berten, John, and Lutz Leisering. 2016. Social Policy by Numbers. How International Organisations Construct Global Policy Proposals. International Journal of Social Welfare 26 (2): 156-167.

Böger, Tobias, and Lutz Leisering. 2018. A New Pathway to Universalism? Explaining the Spread of 'Social' Pensions in the Global South, 1967-2011. Journal of International Relations and Development: 1-31. https://doi. org/10.1057/s41268-018-0152-2.

Boli, John, and George M. Thomas. 1997. World Culture in the World Polity: A Century of International Non-Governmental Organization. American Sociological Review 62 (2): 171-190.

Bromley, Patricia, and Walter W. Powell. 2012. From Smoke and Mirrors to Walking the Talk: Decoupling in the Contemporary World. Academy of Management Annals 6 (1): 483-530.

Brunsson, Nils. 2002. The Organization of Hypocrisy: Talk, Decisions and Actions in Organizations. Herndon, VA: Copenhagen Business School Press.

—. 2007. The Consequences of Decision-Making. Oxford: Oxford University Press.

Calliess, Graf-Peter. 2007. The Making of Transnational Contract Law. Indiana Journal of Global Legal Studies 14 (2): 469-483.

Calliess, Graf-Peter, and Peer Zumbansen. 2010. Rough Consensus and Running Code: A Theory of Transnational Private Law. Oxford: Hart Publishing.

Chorev, Nitsan. 2012. Changing Global Norms through Reactive Diffusion: The Case of Intellectual Property Protection of AIDS Drugs. American Sociological Review 77 (5): 831-853.

Clarke, John. 2005. Welfare States as Nation States: Some Conceptual Reflections. Social Policy and Society 4 (4): 407-415.

Cotterrell, Roger. 2012. What Is Transnational Law? Law \& Social Inquiry 37 (2): 500-524.

Cronin, Bruce. 2002. The Two Faces of the United Nations: The Tension Between Intergovernmentalism and Transnationalism. Global Governance 8: 53-71.

Deacon, Bob. 2007. Global Social Policy and Governance. London: Sage Publications. 
2013a. Global Social Policy in the Making: The Foundations of the Social Protection Floor. Bristol: Policy Press.

2013b. The Social Protection Floor and Global Social Governance: Towards Policy Synergy and Cooperation between International Organizations. International Social Security Review 66 (3-4): 45-67.

Deacon, Bob, Michelle Hulse, and Paul Stubbs. 1997. Global Social Policy. International Organizations and the Future of Welfare. London: SAGE.

Devereux, Stephen, and Rachel Sabates-Wheeler. 2007. Editorial Introduction: Debating Social Protection. IDS Bulletin 38 (3): 1-7.

Dobbin, Frank, Beth Simmons, and Geoffrey Garret. 2007. The Global Diffusion of Public Policies: Social Construction, Coercion, Competition, or Learning? Annual Review of Sociology 33: 449-472.

Esping-Andersen, Gøsta. 1990. Three Worlds of Welfare Capitalism. Cambridge: Polity Press.

Faist, Thomas, Başak Bilecen, Karolina Barglowski, and Joanna Jadwiga Sienkiewicz. 2015. Transnational Social Protection: Migrants' Strategies and Patterns of Inequalities. Population, Space and Place 21: 193-202.

Gerring, John. 2007. Case Study Research: Principles and Practices. Cambridge: Cambridge University Press.

Go, Julian, and Monika Krause. 2016. Fielding Transnationalism: An Introduction. The Sociological Review Monographs 64 (2): 6-30.

Graham, Carol. 2002. Public Attitudes Matter: A Conceptual Frame for Accounting for Political Economy in Safety Nets and Social Assistance Policies. Social Protection Discussion Paper Series, No. 0233. Washington, DC: World Bank Social Protection Advisory Service.

Hall, Peter A. 1993. Policy Paradigms, Social Learning, and the State: The Case of Economic Policymaking in Britain. Comparative Politics 25 (3): 275-296. Hall, Peter A., and Rosemary C.R. Taylor. 1996. Political Science and the Three New Institutionalisms. Political Studies 44: 936-957.

Halliday, Terence C., and Bruce G. Carruthers. 2007. The Recursivity of Law: Global Norm Making and National Lawmaking in the Globalization of Corporate Insolvency Regimes. American Journal of Sociology 112 (4): $1135-1202$.

Hickey, Sam. 2012. Turning Governance Thinking Upside-Down? Insights from the Politics of What Works. Third World Quarterly 33 (7): 1231-1247. Huber, Evelyne, and John D. Stephens. 2012. Democracy and the Left: Social Policy and Inequality in Latin America. Chicago: University of Chicago Press. 
Huntington, Samuel P. 1973. Transnational Organizations in World Politics. World Politics 25 (3): 333-368.

Ikenberry, G. John. 2018. The End of the Liberal International Order? International Affairs 94 (1): 7-23.

Jepperson, Ronald L. 1992. National Scripts: The Varying Construction of Individualism and Opinion across Modern Nation-States. PhD Dissertation, Department of Sociology, Yale University, New Haven, CT.

Jessup, Philip C. 2006. Transnational Law (Extracts). In Philip C. Jessup's Transnational Law Revisited-On the Occasion of the 50th Anniversary of Its Publication, Essays in Transnational Economic Law, No. 50, ed. Christian Tietje, Alan Brouder, and Karsten Nowrot. Accessed 29 September 2019. http://www.wirtschaftsrecht.uni-halle.de/sites/default/files/altbestand/ Heft50.pdf.

Kaasch, Alexandra. 2013. Contesting Contestation: Global Social Policy Prescriptions on Pensions and Health Systems. Global Social Policy 13 (1): 45-65.

Kaasch, Alexandra, and Kerstin Martens. 2015. Actors and Agency in Global Social Governance. Oxford: Oxford University Press.

Kentikelenis, Alexander E. 2017. Structural Adjustment and Health: A Conceptual Framework and Evidence on Pathways. Social Science \& Medicine 187: 296-305.

Kentikelenis, Alexander, and Irene Papanicolas. 2011. Economic Crisis, Austerity and the Greek Public Health System. European Journal of Public Health 22 (1): 4-5.

Kentikelenis, Alexander E., and Leonard Seabrooke. 2017. The Politics of World Polity: Script-Writing in International Organizations. American Sociological Review 82 (5): 1065-1092.

Kentikelenis, Alexander, Lawrence King, Martin McKee, and David Stuckler. 2014. The International Monetary Fund and the Ebola Outbreak. The Lancet Global Health 3 (2): PE69-PE70.

Kentikelenis, Alexander E., Thomas H. Stubbs, and Lawrence P. King. 2016. IMF Conditionality and Development Policy Space, 1985-2014. Review of International Political Economy 23 (4): 543-582.

Keohane, Robert O. 1988. International Institutions: Two Approaches. International Studies Quarterly 32 (4): 379-396.

Keohane, Robert O., and Joseph S. Nye. 1974. Transgovernmental Relations and International Organizations. World Politics 27: 39-62. 
Koh, Harold Hongju. 1996. Transnational Legal Process. Faculty Scholarship Series 2096.

- 2006. Why Transnational Law Matters. Penn State International Law Review 24: 745-753.

Krasner, Stephen D. 1982. Structural Causes and Regime Consequences: Regimes as Intervening Variables. International Organization 36 (2): 185-205. Lavers, Tom, and Sam Hickey. 2016. Conceptualizing the Politics of Social Protection Expansion in Low Income Countries: The Intersection of Transnational Ideas and Domestic Politics. International Journal of Social Welfare 25: 388-398.

Levitt, Peggy. 2001. The Transnational Villagers. Berkeley: University of California Press.

Levitt, Peggy, and B. Nadya Jaworsky. 2007. Transnational Migration Studies: Past Developments and Future Trends. Annual Review of Sociology 33: 129-156.

Levitt, Peggy, and Ninna Nyberg-Sørensen. 2004. The Transnational Turn in Migration Studies. Global Commission on International Migration (GCIM), Global Migration Perspectives, No. 6, Geneva.

Levitt, Peggy, Jocelyn Viterna, Armin Mueller, and Charlotte Lloyd. 2017. Transnational Social Protection: Setting the Agenda. Oxford Development Studies 45 (1): 2-19.

Meyer, John W., and Brian Rowan. 1977. Institutionalized Organizations: Formal Structure as Myth and Ceremony. American Journal of Sociology 83 (2): 340-363.

Meyer, John W., John Boli, George M. Thomas, and Francisco O. Ramirez. 1997. World Society and the Nation-State. American Journal of Sociology 103 (1): $144-181$.

Obinger, Herbert, and Carina Schmitt. 2011. Guns and Butter? Regime Competition and the Welfare State during the Cold War. World Politics 63 (2): 246-207.

Obinger, Herbert, Carina Schmitt, and Peter Starke. 2013. Policy Diffusion and Policy Transfer in Comparative Welfare State Research. Social Policy and Administration 47 (1): 111-129.

Obinger, Herbert, Klaus Petersen, and Peter Starke. 2018. Warfare and Welfare. Military Conflict and Welfare State Development in Western Countries. Oxford: Oxford University Press. 
Risse, Thomas. 2006. Transnational Governance and Legitimacy. In Governance and Democracy. Comparing National, European and International Experiences, ed. Arthur Benz and Yannis Papadopoulos, 179-199. London: Routledge.

Roger, Charles, and Peter Dauvergne. 2016. The Rise of Transnational Governance as a Field of Study. International Studies Review 18: 415-437.

Ruggie, John Gerard. 1982. International Regimes, Transactions, and Change: Embedded Liberalism in the Postwar Economic Order. International Organization 36 (2): 379-415.

Sassen, Saskia. 2006. Territory, Authority, Rights: From Medieval to Global Assemblages. Princeton: Princeton University Press.

2010. The Global Inside the National: A Research Agenda for Sociology. Sociopedia.isa. Accessed 19 December 2018. http://saskiasassen.com/PDFs/ publications/the-global-inside-the-national.pdf.

Scharpf, Fritz W. 1997. Games Real Actors Play: Actor-Centered Institutionalism in Policy Research. New York: Routledge.

Schmitt, Carina. 2015. Social Security Development and the Colonial Legacy. World Development 70: 332-342.

Shriwise, Amanda, Alexander Kentikelenis, and David Stuckler. forthcoming. Universal Social Protection: Is It Just Talk? Sociology of Development.

Slaughter, Anne-Marie. 2004. A New World Order. Princeton, NJ: Princeton University Press.

Strange, Susan. 1982. Cave! Hic Dragones: A Critique of Regime Analysis. International Organization 36 (2): 479-196.

Tarrow, Sidney. 2001. Transnational Politics: Contention and Institutions in International Politics. Annual Review of Political Science 4: 1-20.

Ulriksen, Marianne S., and Nina Dadalauri. 2016. Single Case Studies and Theory-Testing: The Knots and Dots of the Process-Tracing Method. International Journal of Social Research Methodology 19 (2): 223-239.

United Nations General Assembly. 2017. Global Indicator Framework for the Sustainable Development Goals and Targets of the 2030 Agenda for Sustainable Development, A/RES/71/313. Accessed 29 September 2019. https://unstats.un.org/sdgs/indicators/Global\%20Indicator\%20 Framework\%20after\%202019\%20refinement_Eng.pdf.

von Gliszczynski, Moritz, and Lutz Leisering. 2016. Constructing New Global Models of Social Security: How International Organizations Defined the Field of Social Cash Transfers in the 2000s. Journal of Social Policy 45 (2): 325-343. 
Weaver, Catherine. 2008. Hypocrisy Trap: The World Bank and the Poverty of Reform. Princeton, NJ: Princeton University Press.

Wood, Geof, and Ian Gough. 2006. A Comparative Welfare Regime Approach to Global Social Policy. World Development 34 (10): 1696-1712.

Yeates, Nicola. 2001. Understanding Global Social Policy. Bristol: Policy Press.

Yeates, Nicola, and Zoë Irving. 2005. Introduction: Transnational Social Policy. Social Policy \& Society 4 (4): 403-405.

Zumbansen, Peer. 2011. Neither 'Public' nor 'Private', 'National' nor 'International': Transnational Corporate Governance from a Legal Pluralist Perspective. Journal of Law and Society 38 (1): 50-75.

Open Access This chapter is licensed under the terms of the Creative Commons Attribution 4.0 International License (http://creativecommons.org/licenses/ by/4.0/), which permits use, sharing, adaptation, distribution and reproduction in any medium or format, as long as you give appropriate credit to the original author(s) and the source, provide a link to the Creative Commons licence and indicate if changes were made.

The images or other third party material in this chapter are included in the chapter's Creative Commons licence, unless indicated otherwise in a credit line to the material. If material is not included in the chapter's Creative Commons licence and your intended use is not permitted by statutory regulation or exceeds the permitted use, you will need to obtain permission directly from the copyright holder.

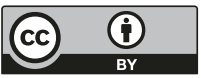

